\title{
Radiolabeling and Biodistribution of Monoclonal Antibody (MAb) Anti-CD20 with Iodine-131
}

\author{
Akinkunmi Ganiyu Akanji, Emiko Muramoto, José de Souza Caldeira Filho, Renata \\ Martinussi Couto and Elaine Bortoletti de Araújo \\ Instituto de Pesquisas Energéticas e Nucleares, IPEN-CNEN, Av. Prof. Lineu Prestes 2242, Cidade Universitária; \\ 05508-900 - São Paulo - SP - Brasil
}

\begin{abstract}
Radioactive isotopes of iodine, mainly iodine-131 have been broadly used in many monoclonal antibody radioiodination settings, employing different methods. In this study, using a Chloramine-T procedure, the influence of incubation time, CT mass, and Ab/activity ratio on the radiochemical yield of the anti-CD20 antibody labeled with iodine-131 was observed. Radiochemical yield was > $97 \%$, employing different Chloramine-T masses, independently of incubation time. Radiochemical purity was above $99 \%$ after purification of the labeled compound. The relationship between $A b$ mass and radioactivity was tested and no difference was observed when $90.6 \mathrm{MB} q$ $(2.45 \mathrm{mCi})$ of activity was incorporated in the Ab-mass range studied. Biodistribution study in normal Swiss mice showed higher uptake by the liver and intestines. Low thyroid uptake indicated a suitable in vivo stability. Slight blood uptake was considered a result of circulating radioactivity in normal organs and tissues. A favorable biological distribution of ${ }^{131}$ I-anti-CD20 suggests this radiopharmaceutical may be effectively used in the therapy of Non Hodgkin Lymphoma.
\end{abstract}

Key words: Monoclonal antibody, radioioactivity, anti-CD20, radioimmunotherapy.

\section{INTRODUCTION}

Radioactive isotopes of iodine have proved to be appropriated for labeling both large and small biomolecules, proteins and peptides. Several therapeutic radioisotopes used for labeling many monoclonal antibodies are available, beta emitters like iodine-131, yttrium-90, rhenium-186, rhenium-188, cupper-67 and alpha emitters like bismuth-212 and astatine-211. The choice and use of these radioisotopes are based on their physical properties, suitable chemistry, advantages and disadvantages $(1,3,5,8)$. The preference for radioiodine, mainly iodine-131, is sustained by its well-known chemistry, easy availability and low cost $(1,3,5)$. There are many methods of radiolabeling proteins with radioiodine, mostly oxidative reactions, as described by many authors like Hunter and Greenwood $(1,5,8)$. However, Chloramine-T, a mild oxidizing agent, can alter protein structure (denaturation) if exposure is prolonged. Using this procedure, the oxidizing process is terminated by addition of a reducing agent, sodium metabisulfite (SMB).

Monoclonal antibodies are hybridomas of polyclonal antibodies with defined specificity; their usefulness as a therapeutical tool is based on three major characteristics: specificity of binding, homogeneity, and possibility of unlimited production, all made possible by the technique

\footnotetext{
*Author for correspondence
} 
developed in 1975 by Köhler and Milstein (2). These biomolecules have been proven to be capable of promoting significant biological effectiveness or damage to selective tumor cells, either conjugated or unconjugated to a radionuclide $(2,3)$.

Furthermore, anti-CD20 antibody is directed against CD20, a surface antigen common in B-cell of lymphoid tissue, in particular, non-Hodgkin's lymphomas (NHL). Rituximab (Rituxan; IDEC pharmaceuticals) was the first unconjugated antiCD20 approved by the FDA in 1997 for cancer therapy (2). Both clinical and pilot trials have proven it to be safe and effective either as a single agent or in combination with chemotherapy $(2,3,7)$.

Most of the commonly used radionuclides in radioimmunotherapy of cancer are beta emitting particles such as iodine-131 and yittrium-90. Both have good chemical properties and suitable halflives of 192 and 64 hours, respectively. Iodine-131 has a maximum energy of $0.61 \mathrm{MeV}$ and path range of $0.7 \mathrm{~mm}$ while yittrium-90 has a maximum energy of $2.27 \mathrm{MeV}$ and path range of $5.2 \mathrm{~mm}$ (2). The two commercially available radiopharmaceuticals approved for clinical treatment of B-cell of non-Hodgkin's lymphoma, ${ }^{131}$ I-Tositumomab (Bexxar) and ${ }^{90}$ Y-Ibritumomab tiuxetan (Zevalin), have both been proven to be efficient in the treatment of chemotherapyrefractory non-Hodgkin's lymphoma $(2,4,7)$. Furthermore, inherent radiosensitivity and high level of CD20 antigen expressed on lymphoma cells contribute wholly to the effectiveness of these drugs (4). However, lower cost, greater availability and ease of antibody labeling result in a considerable advantage of iodine-131 over yttrium-90. Shorter half-lives, marrow toxicity and need for appropriate chelation may be a disadvantage for yttrium-90, while in vivo dehalogenation of iodine-131 is also a disadvantage $(3,4)$.

\section{MATERIALS AND METHODS}

\section{Materials}

Rituximab (Mabthera), a mouse-human chimeric anti-CD20 antibody, was commercially obtained from Roche Brazil S/A (100 mg/10 mL) and stored in aliquots of $100 \mu \mathrm{g} / 10 \mu \mathrm{L}$. Sodium Iodide $\left(\mathrm{Na}^{131} \mathrm{I}\right)$ with high specific activity (Nordion) was employed, Chloramine-T (CT) and Sodium metabisulfite (SMB) were purchased from Merck. To the antibody $(100 \mu \mathrm{g} / 10 \mu \mathrm{L})$ was added $50 \mu \mathrm{L}$ of sodium phosphate buffer (PBS) (0.5 M pH 7.5), followed by $\mathrm{Na}^{131} \mathrm{I}(74 \mathrm{MBq} / 10 \mu \mathrm{L}$ in sterile water, and CT $(10 \mathrm{mg} / 10 \mathrm{~mL})$ solution in PBS $(0.2$ $\mathrm{M} \mathrm{pH} \mathrm{7.5).} \mathrm{The} \mathrm{mixture} \mathrm{was} \mathrm{stirred} \mathrm{for} 3$ minutes at room temperature, and SMB in PBS was added to stop the reaction $(20 \mu \mathrm{g} / 10 \mu \mathrm{L})$.

\section{Purification procedure:}

The reaction mixture was applied to a gel filtration column (Sephadex G-25 PD-10, Pharmacia). The column was eluted with PBS buffer $(0.2 \mathrm{M}, \mathrm{pH}$ $7.5)$ in 15 aliquots of $1 \mathrm{~mL}$. Radioactivity in each fraction was determined, and the fractions containing the desired radioiodinated product was separated.

\section{Quality control}

Two suitable methods were used to verify radiochemical purity of the radiolabeled compound. Instant thin-layer chromatography (ITLC) was performed on Gelman Sciences precoated silica gel plates $(1.5 \times 12 \mathrm{~cm})$, using $85 \%$ methanol as eluent. Electrophoresis was performed with sodium barbital buffer $(0.2 \mathrm{M}, \mathrm{pH}$ 8.6) as solvent on Whatman 1 paper at $300 \mathrm{~V}, 1 \mathrm{~A}$, for 40 minutes.

\section{Biodistribution study in normal Swiss mice}

Twelve normal Swiss mice, weighing $25-35$ g, were administered with approximately $0.74 \mathrm{MBq}$ of ${ }^{131} \mathrm{I}$ - anti-CD20 in $0.1 \mathrm{~mL}$ via lateral tail vein and housed in cages with food and water. Animals were divided into three groups of four, for each time studied, $1 \mathrm{~h}, 4 \mathrm{~h}$, and $24 \mathrm{hs}$, respectively. The animals were sacrificed, the blood was collected, and organs of interest were dissected, rinsed and weighed. Concomitant radioactivities were measured together with standard solutions prepared at the time of injection, in a Packard gamma counter. Percentages of radioactivity dose administered per gram (\% ID/g) were determined.

\section{RESULTS}

The use of the Chloramine- $\mathrm{T}$ radioiodination procedure determined radiochemical yields between 95.23 and $98.0 \%$, regardless of time of incubation (Table 1), and $99.60 \%$ after purification (Table III). The percentage of unbound 
radionuclide fell below $2 \%$ in all cases. A slight variation in radiochemical yield was observed, although not significant when the CT mass was varied at different incubation reaction times, as shown in Table 1. The relationship between antibody mass and radioactivity was tested (see Table 2), and no difference was observed when the same range of radioactivity $(90.6 \mathrm{MBq})$ was incorporated into the $\mathrm{Ab}$ except for a slight reduction at $10 \mu \mathrm{g}$ at all tims studied. A product of high radiochemical purity was obtained after Sephadex G-25 PD 10 gel purification (see Table 3). Results of a normal Swiss mouse biodistribution study are shown in Table 4 . These results are expressed as \% dose/gram.

Table 1- Radiochemical yield employing different CT mass and different incubation reaction time.

\begin{tabular}{c|c|c|c}
\hline \multirow{2}{*}{$\begin{array}{c}\text { CT mass } \\
(\mu \mathrm{g})\end{array}$} & \multicolumn{3}{|c}{ Radiochemical yield (\%) } \\
\cline { 2 - 4 } & 1 incubation time \\
\hline 10 & $95.23 \pm 0.71$ & 3 minutes & 10 minutes \\
\hline 100 & $95.90 \pm 0.51$ & $96.29 \pm 0.13$ & $96.15 \pm 0.22$ \\
\hline 200 & $95.83 \pm 5.21$ & $98.00 \pm 0.02$ & $95.21 \pm 0.04$ \\
\hline
\end{tabular}

$(\mathrm{N}=3)$

Table 2 - Relationship between Antibody mass and Radioactivity and Stability

\begin{tabular}{c|c|c|c}
\hline \multirow{2}{*}{$\begin{array}{c}\text { Antibody / Activity } \\
\text { Mass } \\
(\mu \mathrm{g} / \mathrm{MBq})\end{array}$} & Immediately & 6 hours & 24 hours \\
\cline { 2 - 4 } & & & \\
\hline $100 / 90,6$ & $96.20 \pm 0.14$ & $95.74 \pm 0.27$ & $87.54 \pm 0.71$ \\
\hline $50 / 90,6$ & $95.86 \pm 0.19$ & $95.62 \pm 1.51$ & $87.02 \pm 0.39$ \\
\hline $25 / 90,6$ & $94.71 \pm 0.83$ & $94.42 \pm 1.72$ & $84.87 \pm 0.50$ \\
\hline $10 / 90,6$ & $92.25 \pm 3.87$ & $90.86 \pm 6.45$ & $78.40 \pm 8.18$ \\
\hline
\end{tabular}

$(\mathrm{N}=3)$

Table 3 - Radiochemical yield after purification

\begin{tabular}{c|c|c|c}
\hline \multicolumn{2}{c|}{ Before purification } & \multicolumn{2}{c}{ After purification } \\
\hline Immediately & 24 hours & Immediately & 24 hours \\
\hline $96.27 \pm 0.30$ & $92.55 \pm 0.28$ & $99.60 \pm 0.18$ & $94.00 \pm 2.87$
\end{tabular}

$(\mathrm{N}=3)$

Table 4 - Biodistribution of ${ }^{131} \mathrm{I}$-anti-CD20 in normal Swiss mice

\begin{tabular}{c|c|c|c}
\hline \multirow{2}{*}{ Organ } & $1 \mathrm{~h}$ & $4 \mathrm{~h}$ & $24 \mathrm{~h}$ \\
\cline { 2 - 4 } & $1.15 \pm 0.44$ & $0.28 \pm 0.25$ & $0.32 \pm 0.12$ \\
\hline Brain & $14.31 \pm 2.92$ & $13.46 \pm 10.24$ & $5.23 \pm 1.41$ \\
\hline Lung & $8.05 \pm 2.77$ & $6.03 \pm 1.13$ & $2.46 \pm 0.87$ \\
\hline Heart & $5.88 \pm 2.50$ & $5.51 \pm 1.79$ & $1.96 \pm 0.74$ \\
\hline Spleen & $9.84 \pm 1.41$ & $6.14 \pm 0.94$ & $2.21 \pm 0.60$ \\
\hline Liver & $7.85 \pm 2.96$ & $7.01 \pm 1.54$ & $2.30 \pm 0.50$ \\
\hline Stomach & $1.14 \pm 0.66$ & $1.43 \pm 0.89$ & $0.69 \pm 0.26$ \\
\hline Muscle & $11.21 \pm 2.01$ & $6.84 \pm 1.37$ & $2.46 \pm 1.47$ \\
\hline Kidneys & $2.96 \pm 0.34$ & $3.32 \pm 0.41$ & $1.17 \pm 0.15$ \\
\hline Small intestine & $1.49 \pm 0.12$ & $2.84 \pm 0.55$ & $2.25 \pm 0.16$ \\
\hline Large intestine & $0.61 \pm 0.23$ & $1.96 \pm 0.43$ & $4.64 \pm 1.63$ \\
\hline Thyroid $*$ & - & - & $10.79 \pm 1.43$
\end{tabular}

\footnotetext{
*\% dose/organ $\quad(\mathrm{N}=4)$
} 


\section{DISCUSSION}

Radioiodinated antibodies have been shown to be therapeutically effective in treatment of malignant neoplasm of hematologic or lymphatic origin. Iodine-131, in particular, has the advantage of well-known chemistry, easy availability and low cost (1). This was confirmed in experiments using the CT procedure in which a product of high radiochemical purity and yield was obtained. In the biodistribution study, liver uptake was high, comparable with the antibody distribution. Blood clearance was fast, and the compound was excreted by both renal and intestine routes; thyroid uptake was not high, showing the in vivo stability of the radioiodinated antibody. Radiosensitivity of hematological malignant cells aligned with beta and associated gamma energy of radioiodine and finally the inherent immune effectors mechanisms like apoptosis, complement-dependent cytotoxicity (CDC), antibody-dependent cell-mediated cytotoxicity (ADCC) of monoclonal antibodies makes them (MAbs) suitable for the treatment of these malignances $(1,2,3)$ when labeled with iodine-131.

\section{ACKNOWLEDGEMENTS}

We thankfully acknowledge the IAEA for support in the development of this study.

\section{RESUMO}

Radioisótopos de iodo, principalmente iodo-131 foram muito utilizados em vários procedimentos de marcação de anticorpos monoclonais usando diferentes métodos tais como o de CloraminaT(CT). Neste estudo, observamos a influência de tempo de incubação, massa de CT, relação anticorpo/actividade na pureza radioquímica no anticorpo anti-CD20 marcado com iodo-131. A pureza radioquímica foi superior a $97 \%$ quando massas diferentes de CT foram utilizadas independentes do tempo de incubação. A pureza radioquímica superior a $99 \%$ após a purificação do composto radiomarcado. Todavia, a relação entre anticorpo/atividade foi determinada e nenhuma diferencia foi observada quando $90,6 \mathrm{MBq}(2.45$
$\mathrm{mCi}$ ) foram incorporados a 10, 25, 50 ou $100 \mu \mathrm{g}$ de Ac exceto uma pequena redução em $10 \mu \mathrm{g}$. O estudo de distribuição biológica em camundongo Swiss normais demonstrou captação elevada no fígado e nos intestinos. A baixa captação na tireóide atesta que o produto apresenta estabilidade in vivo satisfatória. Traços de atividade apresentado pelo sangue podem ser considerados como resultado de actividade circulante nos órgãos normais. A distribuição biológica favorável do composto marcado é uma indicação forte à aplicabilidade do radiofármaco na terapia de linfomas não-Hodgkins (LNH).

\section{REFERENCES}

Behr, T. H.; Gottard, M. M.; Becker, W. and Behé, M. (2001), Radioiodination of monoclonal antibodies, proteins and peptides for diagnosis and therapy. Nuklearmedizin, 26, 71-79.

Illidge, T. M. and Brock, S. (2000), Radioimmunotherepy of cancer: using monoclonal antibodies to target radiotherapy. Current Pharm. Design., 6, 1399-1418.

Juweid, M. E. M. D. (2002), Radioimmunotherepy of bcell non-hodgkin's lymphoma: from clinical trials to clinical practice. J. Nucl. Med., 43, 1507-1529.

Schaffland, A. O. P. H. D.; Buchegger, F. M. D.; Kosinski, M. P. H. D. et al. (2004), ${ }^{131}$ I-Rituximab: Relationship Between Immunoreactivity and specific activity. J. Nucl. Med., 45, 1784-1790.

Seevers, R. H. and Consell, R. E. (1982), Radioiodination techniques for small organic molecules. Chem. Rev., 82, 575-590.

Silverman, D. H.; Delpassand, E. S.; Torabi, F. et al. (2004), Radiolabeled antibody therapy in nonHodgkin's lymphoma: radiation protection, isotope comparisons and quality of life issues. Cancer Treatment Reviews., 30, 165-172.

Wahl, R. L. M. D. (2005), Tositumomab and ${ }^{131} \mathrm{I}$ therapy in non-Hodgkin's lymphoma. J. Nucl. Med., 46 : (Suppl.), 128S-140S.

Weadock, K. S.; Sharkey, R. M.; Vergas, D. C. and Goldenberg, D. M. (1990), Evaluation of a Remote Radioiodination System for Radioimmunotherepy. $J$. Nucl. Med., 31, 506-511.
Received: June 28, 2005; Revised: July 14, 2005; Accepted: August 01, 2005. 